\title{
ORGANIZATIONAL CULTURE AS CORRELATE OF TEACHERS' JOB PERFORMANCE AND ATTITUDE TO WORK IN SECONDARY SCHOOLS IN ANAMBRA STATE NIGERIA
}

\section{Boniface Emengini*, Ada Sam Omenyi* \& Christopher Amobi Nwankwo* http://dx.doi.org/10.4314/og.v16i1.3}

\section{Abstract}

The study investigated organizational culture as correlate of teachers' job performance and attitude to work in secondary schools in Anambra State, Nigeria. Five research questions guided the study and six null hypotheses were tested. The study adopted correlational survey research design. The population of the study comprised all the 6396 teachers in public secondary schools in the state. Out of the population, a sample size of 1279 teachers was drawn through proportionate stratified random sampling techniques. Data was collected using three different questionnaires developed by the researchers. The questionnaires include school organizational culture questionnaire (SOCQ), Teachers' job performance questionnaire (TJPQ) and Teachers' attitude to work questionnaire (TAWQ). The instruments were validated by three experts from Faculty of Education Nnamdi Azikiwe University Awka. Cronbach Alpha method was used to determine the reliability of the instruments which yielded a reliability coefficient of .959, .957 and 0.701 respectively. The reliability indices were considered high enough and thus the instruments were deemed reliable. Data collection was done by the researchers with the help of ten research assistants. Aggregate score was used to answer research questions 1 to 3 while Pearson $r$ was used to answer research questions 4 and 5 and critical probability table of Pearson $r$ was used to take decision on the six null hypotheses at 0.05 level of significance. The findings showed among others that: teachers rated their school organizational culture to be good; teachers' job performance is good and teachers have positive attitude to their work. Also, it was found that there is no significant relationship between school organization culture and teachers' job performance; and no significant relationship between school organizational culture and teachers' attitude to work. Based 
Ogirisi: a new journal of African studies vol. 162020

on the findings it was recommended that: School management and management of Anambra State post primary school service Commission should ensure improvement in secondary school culture in order that all the teachers would rate their school culture to be good without some rating it to be poor. It was also recommended that in- service training be organized for secondary school teachers through seminars, workshops and advance learning in order to ensure that all of the teachers have good job performance and positive attitude to work.

Keywords: Correlate, Organizational Culture, Teachers, Job Performance and Attitude to Work

\section{Introduction}

Development of any nation is primarily dependent on the education system available in the country. Education cannot achieve its essence without teachers playing pivotal roles in ensuring achievement of educational institutions. Accordingly, Joshua and Ifedayo (2012), noted that teachers promote quality education from the domain of teaching and learning through creative ideas, participation and cooperative learning, research, analysis and critical thinking, problem solving, innovation and encouragement of creative and divergent thinking. Same Joshua and Ifedayo (2012) noted that teachers' activities in area of teaching and learning lead to proper development of knowledge, skills, attitudes, values that enable students to function effectively and live as responsible citizens and also make useful contribution to the society.

Therefore, teachers' job performance and teachers' attitudes to work play a crucial role in the students' learning processes. Kamalu, Samsu and Selamat (2013) noted that good performance of the students depend on the effective job performance of their teachers. In the same vein, Ololube (2006) noted that teachers are expected to render a very high job performance and the ministry of education is always curious regarding the job performance of its teachers. As defined by Griffin (2012), job performance is an act of accomplishing or executing a given task. In the school system, a teacher's job performance could be described as the duties performed by a teacher at any given time in school geared towards 
Emengini, Omenyi \& Nwankwo: Organizational Culture as ...

achieving both the daily school and classroom objectives and the entire set goals and objectives of education. Such duties could include among others: covering of scheme of work adequately, give and marking of continuous assessment regularly, be able to manage stubborn students in the class without distorting teaching and learning, preparing plan of any lesson to be taught to mention but a few. From the definitions one would understand that teachers' job performance is sinequanon for the achievement of educational goal at large.

According to Jex and Britt (2008) teacher's job performance can be viewed in two forms: In-role and extra-role. In role performance is about the actions of the employee that fulfill its requirements according to his job description whereas extral-role performance is about the actions that are outside the formal requirements regarding his role. Also job performance should be measured in terms of task performance and contextual performance in order to fully grasp a holistic concept of the latent construct. Contextual job performance consists of behaviours that help support incumbents in delivering their task performance and such behaviours are important to ensure organizational effectiveness. Examples of teachers' contextual job performance include helping a colleague to carry out his or her duties if need be without minding they will not face any consequences of non-completion of such duty by the teacher in charge. Thus, these are duties performed by the teachers even though they are not specifically assigned to them. In other words, teachers perform such duties provided it will lead to the achievement of school goals.

On the other hand, task performance involves the maintenance of the technical core of the organization (Luo, Shi, Li \&Miano, 2008). Example of teacher task performance could be preparation of lesson plan for any lesson to be taught, giving continuous assessment to the students, copying note for the students, teaching proper and the likes. Also, Jex and Brit (2008) asserted that in measuring job performance, it is important to integrate items on the basis of task performance as well as contextual performance or specifically organizational citizenship behaviour (OCB). Thus, teachers' job performance was measured in this study with items from both dimensions of task and contextual performance. 
Ogirisi: a new journal of African studies vol. 162020

According to Aurah and McConnel (2014) teachers' job performance have been influenced by gender. However, Bilali (2013) found that there is no significant difference in job performance level across gender. Although, Bilali's study used student teachers in a university setting which may be different from the setting of employed teachers, gender is gender.

On their attitude, Barros and Marcos (2010), noted that attitudes means individuals' prevailing tendency to respond either favourably or unfavourably to an object (person, group, organization). In other words, attitudes is concerned with an individual's way of thinking and behaving which has serious implications for learners, the teacher, the immediate social group with which individual learning relates the school system as a whole.

Robbins (2005) noted that a person can have thousands of attitudes but in organizational behaviour focuses are on very limited number of work related attitudes. These work related attitudes tap positive or negative evaluations that employees hold about aspects of their work environment. Robbins (2005) noted that most of the research on attitude in $\mathrm{OB}$ has been concerned with three attitudes which include: job satisfaction, job involvement and organizational commitment. Accordingly, Kreitner and Kinicki (2007) opined that work related attitudes include job satisfaction, organizational commitment, alienation and communication. The term job satisfaction refers to a collection of feelings that an individual holds toward his/her job. On the other hand, job involvement according to Robbins (2005) measures the degree which a person identifies psychologically with his or her job and considers his/her perceived performance level important to self-worth. While organizational commitment is defined as a state in which an employee identifies with a particular organization and its goals and wishes to maintain membership in the organization (Robbins, 2005). Alienation, means extent to which staff members feel disappointed with their careers and professional development (Rafferty, 2003). For the purpose of this study, teachers' attitudes towards their work simply mean perceptions, outward and visible postures of the teachers beliefs toward their school work. Thus, in measuring teachers' attitudes this study incorporates items from four types of work related attitudes 
Emengini, Omenyi \& Nwankwo: Organizational Culture as ...

which include job satisfaction, job involvement, organizational commitment and alienation.

According to Dodeen, Ibrahim and Emad (2003) attitudes of teachers have been determined to be influenced by gender. According to them, female teachers have more positive attitudes towards teaching profession as compared to male teachers. In the same vain the study of Hussain, Ali, Khan, Ramzan and Qadeen (2011) revealed that female secondary school teachers have more positive attitudes towards their work as compared to their male counterparts. Also in the study of Maliki (2013), it was found that there is a significant difference between male and female teachers' attitudes towards their work; female teachers' attitudes are more positive to their work than their male counterparts.

However, one factor that might influence teachers' job performance and teachers' attitudes to work is organizational culture. As defined by Davoren (2013), organizational culture is the beliefs, values, rituals and symbols that govern the operating style of the people within an institution. In the view of Ng'ang'a and Nyongesa (2012), it is the specific collection of values and norms that are shared by people and groups in an organization and that control the way they interact with each other and with stakeholder outside the organization. Thus, organizational culture is the set of ideas and assumptions about organization's operation. In other words, organizational culture is about the norms, values and beliefs that employees and management in an organization share. Also, it includes the interaction of employees with each other and with the management. It includes the artifacts and symbols in an organization. Azhar (2003) observed that organizational culture is presumed to have far-reaching implications for employees' performance and attitude to make it an importance topic to understand.

In the secondary schools, facilities, symbols, equipment (school plants) and teaching aids some of which should constitute the school artifact are dilapidated. The deplorable condition of these facilities and teaching aids have led Maiyashi (2001) to have stated that in all part of the country without exception that school environment is not conducive for teaching and learning. 
School organizational culture is all about inter-relatedness among organizational members (collegiality) but in most secondary schools' culture, there seems to be closed principals/teachers relationship as a result of keeping a social distance from the teachers by practicing excessive rules and regulations. In the same vein, Raza (2010) opined that the main reason why some principals choose to keep themselves at distance from teachers and avoid intimating with them is because they are very strict about the rules and regulations of the school. No wonder Kumar (2006) noted that some culture are bureaucratic oriented. Thus, the employee would see everything done in the organization as theirs (the management) and not ours (excluding him/herself). Thus, the value systems that promote staff interest to work for organization include the ones that promote team work, collegial support, innovation, freedom, autonomy, risk taking, use of creativity, supervisory support, empowerment, informal communication, opportunity for advancement, objective feedback and the likes. A fundamental part of the substance of school organizational culture is their values which are assumed to be unique to the school

Therefore, all the secondary schools have organizational culture, some appears to have stronger, more deeply rooted culture than others who may have weak and shallowly rooted cultures (Riley, 2013). Strong culture as defined by Riley (2013) is a culture which is deeply embedded into the ways a school organization does things. Riley noted that with a strong culture, employees and management understand what is required of them and they will try to act in accordance with core values. A key feature of a strong school culture is that there is less need for detailed policies and procedures because the way things are done around here is understood and accepted. In their own opinion, Chatman, Demison, Kuenzi and Schneider (2012) noted that strong culture is one with combination of wide agreement and intensity about norms and values among organizational members. In the context of this study, strong school organizational culture describe an organizational culture adopted by a school with a value system that promotes team work, innovation, freedom or discretion to take risk, supervisory support, use of equitable reward, relationship among teachers and colleagues and with that of principal being open to all which arise as a result of goal 
Emengini, Omenyi \& Nwankwo: Organizational Culture as ...

clarity and goal alignment widely shared among teachers in order to achieve school goal.

On the other hand, weak school culture according to Kumar (2006) is where there is little alignment with organizational values and control must be exercised through extensive procedure and coercion to achieve organizational goals. Riley (2013) opined that weak school culture is one in which the core values are not clearly defined, communicated or widely accepted by those working for the organization. Riley (2013) concurred with Kumar (2006) where he argued that a key consequence of weak organizational culture is the greater need for procedures, policies and bureaucracy in order to get things done. Thus, a weak school culture will emphasize on bureaucracy and policies and excessive control on the teachers toward goal achievement. As used in this study, a weak school culture is one which seeks to guide and influence the teachers to goal attainment through emphasis on bureaucracy, hierarchy, policy, procedure closed management teacher communication and low preference for human needs.

The culture prevailing in a school may have effect on the teachers' job performance and attitude to work. In a study carried out by Kamalu, Samsu and Selamat (2013), it was found that the teachers in a secondary school were unable to carry out their task performance.

In Anambra State, cases of teacher negative attitude to work which lead to poor performance among teachers have been reported (Nduanya, 2000, Uzoechina, 2004). Obineli (2013) noted that some teachers are even looking elsewhere for greener pasture. Other negative attitudes among the teachers in Anambra State according to Obineli (2013) include non-commitment to duty, absenteeism, low morale, lack of interest and dissatisfaction in their teaching job.

Stating on the influence of organizational culture, Aftab (2012), argue that a culture supportive of organizational strategies lead to high performance and positive attitudes to work. Thus, a school culture needs to be supportive and provide such atmosphere where the teachers will be influence to high performance and positive attitude to work. Therefore, the increased importance in teachers' job performance and attitude to work have made it extremely importance to examine organizational culture as 
Ogirisi: a new journal of African studies vol. 162020

determinant of teachers' job performance and attitude to work in secondary schools in Anambra State.

Awoyemi and Ekwoaba (2014) studied on strong organizational culture as a tool for management to control, motivate and enhance/improve employees' performance in selected federal government tertiary institutions in Lagos mainland local government area of Lagos state. Four research questions and four hypotheses were used. Structured questionnaire constituted the major instrument. It was administered on 120 employees of personnel departments of these institutions. Descriptive and inferential statistics were used for data analysis. The response rate was $90 \%$ as only 108 were filled questionnaire. The result showed that organizational culture is a two edged sword that can cut across both management and employees and therefore should be encouraged if it will lead to productivity and increase on performance. If not, other means of achieving performance should be employed. This study indicates that organizational culture is ambiguous and can lead to closure of mind and restriction and reduction of autonomy. The study is related to the present study because, it is on organizational culture and employees job performance. Also it was carried out in Nigeria setting. However, it was carried out in tertiary institutions and not in secondary schools. Moreover, it was done in Lagos State and not in Anambra State.

In another study by Kashyap, Vohra and Kaur (2012) titled the comparative analysis of organizational culture: The empirical study of IT organization in the region of Mohali Punjab, India. The purpose of the study was to assess the extent of culture prevailing in Indian IT organizations. 100 employees working in four organizations covering IT sector in Muhali forms the sample of the study. The study emphasizes on comparative analysis of the organizational culture in IT industries. Three research question and four hypotheses were used. Primary data was collected with the help of a survey which use OCTAPACE profile, a standardized tool for cultural assessment. To collect the primary data in the first stage, 28 employees from each of the organizations under study were selected using random sampling. In second stage the data was analyzed by calculating the mean scores of the dimensions of the culture and variation in four organizations with one way ANNOVA. The 
Emengini, Omenyi \& Nwankwo: Organizational Culture as ...

findings suggest that human resources manager could consider employees as important stakeholder as far as organizational culture is concerned. The study is related to the present study because the respondent were employees of the organizations involved. But it was not carried out in school setting.

Yesil and Kaya (2012) studied the role of organizational culture on innovation capability in Turkey: An empirical study. Because creating and sustaining competitive advantages is the number one priority of any organization and that companies try to be competitive through continuous building of their innovation capacity and creating innovative product and services the researchers according to them went into the study. The study was conducted on population of eight thousand firm managers with sample size of 2050 managers. Questionnaires were used to collect data. Four research question and four research hypothesis were developed from the related literatures and tested through the data collected from managers of firms in Turkey. Data was analyzed via smart PLS program. The results revealed that majority of the companies have good organizational culture. The results also provide evidence regarding the implication of organization culture as well as enabling factor behind innovativeness of the firms. Other cultural dimension according to them namely clan and hierarchy were not related to innovation capability of the firm. Although the study was on organizational culture, but the dimension of culture studied is different from that which this study focused on. Also, the study was not carried out in school rather on firms in Turkey.

Karr (2011) conducted a study titled the attitude of teachers towards teaching reading in the content areas in secondary schools in south Trinidad. The purpose of the study was to determine the attitude of secondary school teachers towards teaching reading in the content areas and investigate whether the significant difference exists in their attitude towards content literacy instruction with respect to variables such as pedagogical training, gender, experience and subject areas. Three research questions and four hypotheses guided the study. The population was consisted of all the teachers in the school. 86 teachers on roll five teachers could not be contacted during the period of the interview. The instrument for data collection was questionnaire. The surveys were therefore given to 81 teachers 
Ogirisi: a new journal of African studies vol. 162020

(94\%) of the population which consisted of 53 females (65\%) and 28 males $(35 \%)$ ratio of approximately $2: 1$ females to male. Afterwards, the scores were used with the SPSS software to calculate the mean, standard deviation and standard error of the mean for each variable as well as to perform either the t-test or ANOVA depending on number of groups in each variable. The result revealed among others that teachers in a secondary school in south Trinidad possessed an average attitude towards teaching reading in the content areas. Thus, the finding suggests that the training received by teachers was not appropriate for creating a high positive attitude towards teaching reading in the content area. The study is related to the present study because, it was aimed at finding out teachers' attitudes in an aspect of their work (teaching reading) and also the fact that it was carried out at the secondary school levels and respondents were teachers.

In a study carried out by Aftab, Rana and Sarwar (2012) on investigation of the relationship between organizational culture and employee's role based performance: Evidence from the banking sector in Pakistan, Variable of the culture include coordination/integration, adaptability, empowerment, customer focus while employee's role based performance was a combination of job, career, innovator, while elements were quality of work, quantity of work, accuracy of work, customer service. The area of the study was Pakistan. The design was a correlational study. Four research questions and four research hypotheses guided the study. The population of the study comprises of all the employees having designation of AVP, OG - I, OG - II and OG - III. Sample size was 400 employees working in the bank on the designation level of middle level managers. Questionnaire was used as instrument for data collection and was based on two main variables: organizational culture and role based performance. Total items of the questionnaire were 67 and were measured by using likert scale. Correlational analysis was performed within and across the variables. Considering all the dimension of organizational culture and performance level, correlational coefficient value is high showing a positive relationship between organization culture and role based performance. The study is related to the present study because it investigated the relationship between organizational culture and employees' role based performance. Thus, the respondents were the employees. On the 
Emengini, Omenyi \& Nwankwo: Organizational Culture as ...

other hand, the fact that the cultural dimensions studied were different from that of the present study and also the setting (Banking Sector) and the location not in Nigeria.

In another study by Kamalu, Samsu and Selamat (2013) on impact of organizational climate on performance in Malaysia, the purpose of the study was to find out the effect of organizational climate on performance in the district of Klang. The design was a descriptive survey. Four research questions and four hypotheses guided the study. 260 teachers in the district of Klang comprise the population of the study. 37 secondary school teachers in the district of Klang participated in the study. They were selected based on simple random sampling. Data were collected using the survey method and were analyzed using descriptive statistics and inferential statistic. Based on the data collected, the findings showed that teachers in a secondary school were unable to carry out their tasks and the organizational climate in the school was unhealthy. The study also showed that organizational climate was found to be a significant factor that could affect teachers' performance. In terms of organizational climate dimension, one aspect of principals' leadership behavior and teachers' behavour thrust and hindrance were found to be critical factors in enhancing performance. The implications to the role of principal is that principals should exercise positive job behavior and do not over emphasized on paper work as it would benefit teachers' classroom instructions. In his contribution Raza and Arids (2010) noted that in cases where teachers are burdened with paper work and administrative duties, teaching and learning process may be affected. Even though the study is related to the present study, it is worthy to note that organizational climate can only be effect of organizational culture, thus organizational culture is broader. Moreover, the study was carried out in Malaysia and not in Nigeria.

Adeyemi (2008) conducted a study on organizational climate and teachers' job performance in primary schools in Ondo State, Nigeria. The purpose of the study was to find out the relationship between organizational climate and teachers' job performance in primary schools in Ondo State. The study was a correlation study. Three research questions and four hypotheses guided the study. The population comprise of all the teachers in 
government owned secondary school in the State. Questionnaire was the instrument for data collection and the data was analyzed using spearman product correlation coefficient. Also, 360 school in the state participated. Findings revealed that most of the schools run an open climate/cultural types. However, the level of organizational climate in most of the schools was very poor. Also it was found that the level of teachers' job performance was equally low. Thus, it was found that there was a relationship between organizational climate and teachers' job performance. However, the study using organizational climate and organizational climate been just an aspect or effect of organizational culture cannot be used to generalize organizational culture effect on teachers' job performance. Moreover, the study was carried out in primary school in Ondo State and not in secondary school neither was it carried out in Anambra State.

In Raza and Arids (2010) study, they examine the impact of organizational culture on performance of college teachers in Punjab. The study was a correlational survey. Four research questions and four hypotheses guided the study. The population of the study comprise of all the college principals and teachers in Punjab. 59 principals and 1500 teachers were sampled from the population. Seventy items questionnaires were used to collect data and were measured by using likert scale. The results of their study revealed principals perceived that behaviour of teachers and production emphasis behaviour of principals were correlated to teachers' job performance. Also, most of the principals perceived that their leadership behaviour such as consideration and aloofness were negatively correlated to teachers' job performance while intimacy behaviour of teachers is slightly correlated to teachers' job performance. However, the organizational culture dimension studied is different from the cultural dimension under investigation in the present study. Also, the above study was carried out in Punjab and not in Nigeria neither is it in Anambra State.

Despite these studies, empirical evidence for a relationship between organizational culture and teachers' job performance is still rather weak. This is caused to some extent, by the fact that various conceptualizations and operationalization of school culture were used in the aforementioned studies. Morevoer, Kamalu, Samsu and 
Emengini, Omenyi \& Nwankwo: Organizational Culture as ...

Selamat (2013) disagreed on work oriented management style of the principal to ensure performance and positive attitude to work among teachers while, Raza and Arids (2010) found that work emphasis behaviour of principal lead to teachers' job performance. Also Ogunbowale (2007) from his finding recommended open, interactive and consideration of teachers by the principals as one that would ensure a good climate which will lead to high performance among teachers while in Raza and Arids (2010) they found that principals perceived that their leadership behaivour such as consideration and aloofness were negatively correlated to teachers' job performance. From the overview, it becomes clear that there is a barrier in drawing conclusions on the relationship between culture and performance. Furthermore, performance was measured in part of the studies by means of perceptions of effectiveness instead of by standardized measures. As the study of Cheng (1993) indicates, the use of perceptions of performances in research in organizational culture may indicate significant findings, whereas such a relationship may not be found if objective performance measures are used as criterion variables.

In a study carried out by Sullivan (2010) titled the influence of school culture, school goals and teacher collaboration on teachers' attitudes towards their professional development plan in the Owen Public schools, Atlantic city. The purpose of the study was to investigate the influence of school culture, school goals, and teacher collaboration on teachers' attitudes towards their professional development plans. The sample was composed of 154 prekindergartens through high school teachers within one school district. Data were collected using questionnaire. Participants held a range of attitudes from very positive to very negative toward professional development plan. Significant relationships were found between four out of five factors of school culture and teachers' attitudes towards professional development plans. The factors of school culture -collaborative and unity of purpose were shown to be associated with teachers' attitudes towards professional development plan. Of the five school culture factors, only the factor professional development was a significant predictor of teachers' attitudes toward professional development plan. Moreover, one other aim of the research was to discover the extent to which PDPs conducted 
individually and PDPs conducted collaboratively differed on teachers' attitude toward PDP. The data showed a moderate effect size that suggested the variance in TAPDP scores was accounted for by whether a teacher collaborated with other teachers on a PDP or whether it was an individual effort. As to determine the extent to which PDPs aligned with school goals and PDPs not aligned with school goals differed on teacher attitudes toward professional development plan, the data indicate a very large effect size and highlighted that a very large portions of the variance in TAPDP scores was accounted for by whether a teacher aligned the PDP with a school goal or whether the PDP had little or no alignment with a school goal. The study is related to the present study because it investigates school culture among other variables and how school culture influence teachers' attitudes towards professional development plan.

In another study by Wang (2007) titled organizational culture, organizational commitment and attitude toward organizational reform in Da-yeh -comprehensive high schools as example. The researcher used questionnaire for the attitude toward organizational commitment and organizational reform and recovered 545 valid questionnaires. One-way ANOVA, scheffe multiple comparison method, Pearson product moment correlation and regression analysis were used to compared the difference and situation in organizational culture, organizational commitment and attitude toward organizational reform among teachers. The researcher found that; there is significance difference in organizational culture among comprehensive high schools of different types, size and between public and private. There is significant difference in attitude toward organizational reform by teachers of different genders, ages, service time, present positions. There is significant correlation among organizational culture, organizational commitment by teachers and attitude by teachers toward organizational change for comprehensive high schools. There is also a significant influence of organizational culture for comprehensive high schools on the attitude towards organizational reform. It was recommended that school management should elevate school culture level, strengthen communication with teachers and continue to execute the policy of comprehensive high school. Also 
Emengini, Omenyi \& Nwankwo: Organizational Culture as ...

those teachers should comply with school values and make commitments in observing it. The study no doubt is related to the present study because organizational culture serves as one of the independent variable and teachers' attitudes as dependent variable. Also, the study was carried out in school setting. However, the study was not carried out in Nigerian setting neither was it in Anambra State.

The problem then is how do teachers' perception of school organizational culture relate with their job performance and attitude to work in secondary schools in Anambra State?

\section{Purpose of the Study}

The main purpose of this study was to find out how organizational culture determines teachers' job performance and attitude to work in secondary schools in Anambra State. Specifically, this study sought:

1. To find out rating scores of teachers on the school organizational culture existing in secondary schools in Anambra State.

2. To find out teachers' job performance scores in secondary schools in Anambra State.

3. To find out teachers' scores on their attitude to work in secondary schools in Anambra State.

4. To determine the relationship existing between the school organizational culture scores of the teachers and their job performance scores in Secondary Schools in Anambra State.

5. To determine the relationship existing between the school organizational culture scores of the teachers and their attitude to work scores in Secondary Schools in Anambra State.

\section{Scope of the Study}

This study focused on organizational culture as determinant of teachers' job performance and attitude to work in secondary schools in Anambra State. Content wise, it involved school organizational culture, teachers' job performance and teachers' attitude to work. It was carried out in the public secondary schools in all the six 
Ogirisi: a new journal of African studies vol. 162020

education zones in the state. The subjects were all the teachers in public secondary schools in Anambra State.

\section{Research Questions}

The following research questions guided the study:

(1) What are the teachers' school organizational culture scores in secondary schools in Anambra State?

(2) What are the teachers' job performance scores in secondary schools in Anambra State?

(3) What are the teachers' attitudes to work scores in secondary schools in Anambra State?

(4) What relationship exists between teachers' school organizational culture scores and teachers' job performance scores in secondary schools in Anambra State?

(5) What relationship exists between teachers' school organizational culture scores and teachers' attitudes to work scores in secondary schools in Anambra State?

\section{Hypotheses}

The following hypotheses were formulated and tested at 0.05 alpha levels.

(1) The relationship existing between teachers' school organizational culture scores and their job performance scores will not be significant.

(2) The relationship existing between school organizational culture scores and teachers' attitude to work scores will not be significant.

(3) The relationship existing between school organizational culture scores and male teachers' job performance scores will not be significant

(4) The relationship existing between school organizational culture scores and female teachers' job performance scores will not be significant.

(5) The relationship existing between school organizational culture scores and male teachers' attitude to work scores will not be significant. 
Emengini, Omenyi \& Nwankwo: Organizational Culture as ...

(6) The relationship existing between school organizational culture scores and female teachers' attitude to work scores will not be significant.

\section{Method}

\section{Research Design}

This study is a correlational survey design, which is a type of descriptive research design concerned mainly with describing events as they are without manipulation of what is being observed. Correlational study seeks to establish what relationship exists between two or more variables. According to Nworgu (2015), a correlational study is one which seeks to establish what relationship exists between two or more variables. Thus, in this study, this design was used to clarify through the use of correlation coefficients if school organizational culture determines teachers' job performance and teachers' attitude to work in Anambra State Secondary schools.

\section{Population of the Study}

The population of the study consisted of all 6,396 teachers who are teaching in the 256 government owned secondary schools in the state as of the time of this study. The selection of the population was based on the data obtained from Anambra State Post Primary School Service Commission at Awka (2019). In the population Aguata education zone has 836 teachers of which 173 are male teachers and 663 are female teachers. Awka education zone has 1711 out of which there are 254 male teachers and 1457 female teaches. Nnewi education zone has 1005 with 166 representing the male teachers and 839 the female teachers in the population. Ogodi has 980 teachers out of which 132 are males and 848 are females. Onitsha education zone has 1397 teachers out of which 118 are male teachers and 1279 are female teachers. And finally, Otuocha education zone has 467 teachers out of which 202 teachers are males while the females are 265 .

\section{Sample and Sampling Technique}

The sample for this study comprised 1279 respondents. In selecting this sample, proportionate stratified-random sampling technique was adopted. This is to ensure that sub-groups in the population 
participate in the study in the same proportion as they exist in the population. To do this, the teachers in the secondary schools were stratified on the basis of the education zones where they are located. From each education zone, approximately 20 percent of the teachers were selected. Also, $20 \%$ each was taken from both male and female numbers in the population respectively. Therefore, 168 teachers were selected from Aguata zone (male 35 and female 133), 342 from Awka zone (male 51 and female 291), 201 from Nnewi zone (male 33 and female 168), 196 from Ogidi zone (male 26 and female 170), 279 from Onitsha zone (male 24 and female 256) and 93 from Otuocha zone (male 40 and female 53), thus, bringing the total sample size of 1279 respondents (male 209 and female 1070).

\section{Instrument for Data Collection}

The researchers constructed three questionnaires namely: School Organizational Culture questionnaire, Teachers' Job Performance questionnaire and Teachers' Attitudes to work Questionnaires. The construction of the questionnaires was guided by a collection of views and findings from related literature and survey instruments. The questionnaires have two parts each (parts A\& B) with Part A sorting for personal data of the respondents like gender. Thus, part B of organizational culture questionnaire contain 50 items with a four points scale ranging from Always (ALW), Most often (MST OFTN), Rarely (RLY) and Never (NV).Part B of teachers' job performance questionnaire comprises of 30 items with options ranging from Strongly Agree -4 points, Agree -3 points, Disagree- 2points and Strongly Disagree -1 point. And part B of teachers' attitudes to work questionnaire comprises of 24 items with options ranging from Strongly Agree - 4points, Agree- 3 points, Disagree- 2points and Strongly Disagree- 1 point. The respondents are instructed on how to respond to items in the questionnaires.

\section{Validation of the Instruments}

Draft copies of the questionnaires alongside with the research purpose, research questions and hypotheses were submitted to two experts in educational management and policy and an expert in measurement and evaluation for face and content validity. These experts were requested to examine the items in terms of its content 
Emengini, Omenyi \& Nwankwo: Organizational Culture as ...

relevance, item clarity, as well as to ascertain if the items were related to the objectives of the study. After scrutinizing the instruments, they offered useful suggestions which were incorporated immediately.

\section{Reliability of the Instruments}

The Cronbach alpha method of reliability was applied. In doing this, the researchers administered the questionnaires on a sample of 40 teachers from secondary schools in Enugu State of Nigeria because Enugu State has the same boundary with Anambra State and also they both have similar values and culture. The researchers waited for them to complete the questionnaire before retrieving them. Part B of organizational culture questionnaire yielded a Cronbach alpha coefficient or Cronbach alpha of .959 while the part B of teachers' job performance questionnaire yielded a coefficient of .957. The part B of teachers' attitudes to work questionnaire yielded a coefficient of .701. The results were indications of the internal consistency of the instruments. Suwannoppharat and Kaewa-ard (2015) noted that reliability coefficient of .696 and above is acceptable. Thus, the reliability coefficients of the three instruments are considered satisfactory for the study.

\section{Method of Data Collection}

Direct approach method of data collection was adopted by the researchers in distributing copies of the questionnaires to ensure maximum recovery of the questionnaires administered. Copies of the questionnaires were distributed to the respondents by the researchers and 10 research assistants who are post graduate student of NnamdiAzikiwe University Awka. These research assistants were trained on how to administer the questionnaires. Training involved explaining properly the location of the sampled schools and the number of teachers selected in each school. Also, the categories of teachers selected with respect to gender and their numbers in each school were explained to the research assistants. A total of 1,279 copies of the questionnaires were administered and 1269 were recovered and used for analysis. 
Ogirisi: a new journal of African studies vol. 162020

\section{Method of Data Analysis:}

For data analysis, the researchers used aggregate scores, Pearson product moment correlation, critical probability table of Pearson $r$. Research questions 1-3 were answered using the aggregate scores while Pearson $r$ was used to answer research questions $4 \& 5$ and the critical probability table of Pearson $r$ was used to test the six null hypotheses at $p<0.05$ level of significance.

For interpretation of correlation coefficient, Onunkwo (2002:216) have it that;
0.8 to $1.0=$ very high relationship
0.6 to $0.8=$ high relationship
0.4 to $0.6=$ Average relationship
0.2 to $0.4=$ low relationship
0.0 to $0.2=$ Very low or no relationship.

\section{Results}

\section{Research Question 1}

What are the teachers' perceived school organizational culture scores in secondary school in Anambra state?

Table 1: Range of scores of teachers' on their school organizational culture

\begin{tabular}{lll}
\hline Range of scores & $\mathrm{N} \%$ & Remarks \\
\hline $50-124$ & 292.3 Poor organizational culture \\
$125-200$ & 1240 & 97.7 Good organizational culture \\
\hline
\end{tabular}

Table 1 shows that 1240 (97.7\%)of the teachers with the scores ranging from 125 to 200perceived their school organizational culture to be good, while $29(2.3 \%)$ others who scored between 50 and 124 perceived their school organizational culture to be poor.

\section{Research Question 2}

What are the job performance scores of secondary school teachers in Anambra state? 
Emengini, Omenyi \& Nwankwo: Organizational Culture as ...

Table 2: Range of scores on teachers' job performance

\begin{tabular}{lccc}
\hline Range of scores & $\mathrm{N}$ & $\%$ & Remarks \\
\hline $30-74$ & 136 & 10.7 & Poor job performance \\
$75-120$ & 1133 & 89.3 & Good job performance \\
\hline
\end{tabular}

Table 2 indicates that $1133(89.3 \%)$ of the teachers with the scores ranging from 75 to 120 have good job performance, while $136(10.7 \%)$ others who scored between 30 and 74 have poor job performance.

\section{Research Question 3}

What are the attitude to work scores of secondary school teachers in Anambra state?

Table 3: Range of scores on teachers'attitude to work

\begin{tabular}{lccc}
\hline Range of scores & $\mathrm{N}$ & $\%$ & Remarks \\
\hline $24-59$ & 203 & 16.0 & Poor attitude to work \\
$60-96$ & 106684.0 & Good attitude to work \\
\hline
\end{tabular}

Table 3 reveals that $1066(84.0 \%)$ of the teachers with the scores ranging from 60 to 96 have good attitude to work, while 203(16.0\%) others who scored between 24 and 59 have poor attitude to work.

\section{Research Question 4}

What relationship exists between the teachers'perceived school organizational culture and their job performance in secondary schools?

Table 4: Pearson $r$ on teachers'perceived school organizational culture and their job performance

\begin{tabular}{llccc}
\hline Source of Variation & $\mathrm{N}$ & Org.Culture $\mathrm{r}$ & Jobperformance $\mathrm{r}$ & Remark \\
\hline Org. Culture & 12691.00 & 0.14 Very low or no Positive \\
& & & & Relationship \\
Job performance & 1269 & 0.14 & 1.00 & \\
\hline
\end{tabular}

Table 4 reveals that there is very low or no positive relationship of 0.14 existing between the teachers' perceived school 
Ogirisi: a new journal of African studies vol. 162020

organizational cultureand their job performance in secondary schools.

\section{Research Question 5}

What relationship exists between the teachers'perceived school organizational culture and their attitude to work in secondary schools?

\section{Table 5: Pearson $r$ on teachers'perceived school organizational} culture and their attitude to work

\begin{tabular}{lcccc}
\hline Source of Variation & $\mathrm{N}$ & Org. Culture $\mathrm{r}$ & Job performancer & Remark \\
\hline Org. Culture & 1269 & 1.00 & 0.02 & $\begin{array}{l}\text { Very low or no } \\
\text { Positive Relationship }\end{array}$ \\
Job performance & 1269 & 0.02 & 1.00 & \\
\hline
\end{tabular}

Table 5 reveals that there is very low or no positive relationship of 0.02 existing between the teachers' perceived school organizational cultureand their attitude to work in secondary schools.

\section{Null Hypothesis 1}

The relationship existing between the teachers'perceived school organizational cultureand their job performance in secondary schools is not significant.

Table 6: Significant of Pearson $r$ on the Teachers'School Organizational Cultureand their Job Performance Using Probability Table of $\mathbf{r}$.

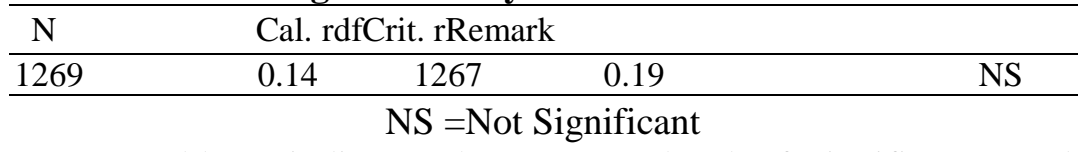

Table 6 indicates that at 0.05 level of significance and $1267 \mathrm{df}$, the calculated r0.14 is less than the critical r0.19. Therefore, the first null hypothesis is accepted. The relationship existing between the teachers'school organizational cultureand their job performance in secondary schools is not significant. 
Emengini, Omenyi \& Nwankwo: Organizational Culture as ...

\section{Null Hypothesis 2}

The relationship existing between the teachers'perceived school organizational culture and their attitude to work in secondary schools is not significant.

Table 7: significant of Pearson $r$ on the teachers'school organizational culture and their attitude to work using probability table of $\mathbf{r}$.

\begin{tabular}{llllll}
\hline $\mathrm{N}$ & Cal. $\mathrm{r}$ & dfCrit. $\mathrm{r}$ & Remark \\
\hline 1269 & 0.02 & 1267 & 0.19 & NS \\
\hline \multicolumn{5}{c}{ NS =Not Significant } \\
\hline
\end{tabular}

Table 7 reveals that at 0.05 level of significance and $1267 \mathrm{df}$, the calculated $\mathrm{r} 0.02$ is less than the critical $\mathrm{r} 0.19$. Therefore, the second null hypothesis is accepted. The relationship existing between the teachers'school organizational culture and their attitude to work in secondary schools is not significant.

\section{Null Hypothesis 3}

The relationship existing between the male teachers'perceived school organizational culture and their job performance in secondary schools is not significant.

Table 8: significant of Pearson $r$ on the male teachers'school organizational culture and their job performance using probability table of $\mathbf{r}$.

\begin{tabular}{lccccc}
\hline $\mathrm{N}$ & Cal. $\mathrm{r}$ & dfCrit. $\mathrm{r}$ & Remark \\
\hline 204 & 0.07 & 202 & 0.19 & & NS \\
\hline \multicolumn{5}{c}{ NS =Not Significant }
\end{tabular}

Table 8 shows that at 0.05 level of significance and 202df, the calculated r0.07 is less than the critical r0.19. Therefore, the third null hypothesis is accepted.

The relationship existing between male teachers' perceived school organizational culture and their job performance in secondary schools is not significant. 
Ogirisi: a new journal of African studies vol. 162020

\section{Null Hypothesis 4}

The relationship existing between the female teachers'perceived school organizational culture and their job performance in secondary schools is not significant.

Table 9: significant of Pearson $r$ on the female teachers'school organizational culture and their job performance using probability table of $\mathbf{r}$.

\begin{tabular}{llllll}
\hline $\mathrm{N}$ & Cal. $\mathrm{r}$ & dfCrit. $\mathrm{r}$ & Remark \\
\hline 1065 & 0.17 & 1063 & 0.19 & NS \\
\hline \multicolumn{5}{c}{ NS =Not Significant } \\
\hline
\end{tabular}

In table 9 it was observed that at 0.05 level of significance and $1063 \mathrm{df}$, the calculated $\mathrm{r} 0.17$ is less than the critical $\mathrm{r} 0.19$. Therefore, the fourth null hypothesis is accepted. The relationship existing between female teachers'school organizational culture and their job performance in secondary schools is not significant.

\section{Null Hypothesis 5}

The relationship existing between the male teachers'perceived school organizational culture and their attitude to work in secondary schools is not significant.

Table 10: significant of Pearson $r$ on the male teachers'school organizational culture and their attitude to work using probability table of $\mathbf{r}$.

\begin{tabular}{lllll}
\hline $\mathrm{N}$ & Cal. $\mathrm{r}$ & dfCrit. $\mathrm{r}$ & Remark \\
\hline 204 & 0.03 & 202 & 0.19 & NS \\
\hline \multicolumn{5}{c}{ NS =Not Significant }
\end{tabular}

Table 10 reveals that at 0.05 level of significance and $202 \mathrm{df}$, the calculated $\mathrm{r} 0.03$ is less than the critical $\mathrm{r} 0.19$. Therefore, the fifth null hypothesis is accepted. The relationship existing between the male teachers'school organizational culture and their attitude to work in secondary schools is not significant. 
Emengini, Omenyi \& Nwankwo: Organizational Culture as ...

\section{Null Hypothesis 6}

The relationship existing between the female teachers'perceived school organizational culture and their attitude to work in secondary schools is not significant.

Table 11: significant of Pearson $r$ on the female teachers'school organizational culture and their attitude to work using probability table of $\mathbf{r}$.

\begin{tabular}{lllll}
\hline $\mathrm{N}$ & Cal. rdfCrit. $\mathrm{r}$ & \multicolumn{1}{c}{ Remark } \\
\hline 1065 & 0.02 & 1063 & 0.19 & NS \\
\hline \multicolumn{5}{c}{$\mathrm{NS}=$ Not Significant }
\end{tabular}

Table 11 indicates that at 0.05 level of significance and $1063 \mathrm{df}$, the calculated $\mathrm{r} 0.02$ is less than the critical $\mathrm{r} 0.19$. Therefore, the sixth null hypothesis is accepted. The relationship existing between the female teachers'school organizational culture and their attitude to work in secondary schools is not significant.

\section{Discussion of Findings}

The findings were discussed under the following subheadings:

i. Perception scores of teachers on the school organizational culture existing in secondary schools.

ii. Teachers' job performance in secondary schools

iii. Teachers' attitude to work in secondary schools

iv. The relationship existing between the school organizational culture and teachers' job performance in secondary schools

v. The relationship existing between school organizational culture and teachers' attitude to work

\section{Perception Scores of Teachers on the School Organizational Culture Existing in Secondary Schools}

The study found that majority of the teachers perceived their school organizational culture to be good as against few ones who perceived their school organizational culture to be poor. The above finding agreed to the result of Yesil and Kaya (2012) who found that majority of the companies in Turkey have good organizational culture. The finding is also related to that of Adeyemi (2008) who found that most secondary schools run humanistic culture. The 
Ogirisi: a new journal of African studies vol. 162020

reason for the similarity in the findings may be as a result of the fact that some cultural variables or indices of organizational culture that were used in their works were considered in this study. Also, both the study of Adeyemi (2008) and the present study except that of Yesil and Kaya (2012) were carried out in Nigerian education setting, thus having teachers as the respondents.

\section{Teachers' Job Performance in Secondary Schools}

With regards to this, it was found that majority of the teachers in secondary schools have good job performance as against few others who have poor job performance. This finding collaborate with that of Amin, et al (2013) who found expressed teachers' job performance to be above average and was good. However, this finding disagreed with the work of Joshua and Ifedayo (2012), Kamalu, Samsu and Selamat (2013) and that of Adeyemi (2008) who revealed that teachers' performance are poor, teachers were unable to carry out their task performance and teachers' job performance being low respectively. The disagreement of the result of this study with that of those just mentioned could be as a result of the fact that teachers' task performance were measured in their studies with perception of teachers' job performance while task performance is just an aspect of job performance and cannot constitute the full construct of teachers' job performance.

\section{Teachers' Attitude to their Work in Secondary Schools}

This study found out that majority of teachers in secondary schools in Anambra state have positive attitude to their work while very few others have negative attitude to their work. Thus, the conclusion that teachers' attitude in secondary schools is good. This result slightly deviates from the finding of Karr (2011) who revealed that teachers in secondary schools possessed average attitude to their work. However, the slight disagreement in the findings could be based on the fact that the work of Karr (2011) was carried out in south Trinidad and not in Nigerian setting neither is it in Anambra state. 
Emengini, Omenyi \& Nwankwo: Organizational Culture as ...

\section{Relationship Existing between Teachers' Perceived School Organizational Culture and their Job Performance in Secondary Schools}

Another finding of this study shows that there is very low or no positive relationship existing between the teachers' perceived school organizational culture and their job performance in secondary schools. Thus, the relationship between teachers' perceived school organizational culture and their job performance in secondary schools is not significant. Also, found is that the relationship existing between both males and females' perceived school organizational culture and their job performance is not significant. The above findings contradict Aftab, Rana and Sarward (2012) who asserted that there is high positive relationship between organizational culture and role based performance of employees. However, the disagreement in the findings could be as a result of the fact that the work of Aftab, Rana and Sarward (2012) was carried out in the banking sector in Pakistan thus, the difference in the respondents of the two studies and the ethics of the two organizations could bring about the difference in the results.

\section{Relationship between Teachers' Perceived School Organizational Culture and their Attitude to Work in Secondary Schools}

This study also found that there is very low or no positive relationship existing between the teachers' perceived school organizational culture and their attitude to work in secondary schools. Thus, the finding shows that relationship existing between teachers' perceived school culture and their attitude to work is not significant. Also, found is that there is no significant relationship found between school culture either as perceived by male or female teachers and their attitude to work in secondary schools. However, the above findings contradict those of Sullivan (2010) and Wang and Hwang (2007) whose studies found that there is significant relationship between school organizational culture and teachers' attitude to work. Moreover, Wang and Hwang (2007) also found that there is significant difference between male and female teachers' attitude to their work. However, the disagreement in the findings of the past researchers mentioned above and that of the present study 
Ogirisi: a new journal of African studies vol. 162020

could be based on the fact that those were carried out not in Nigeria. Thus, the different in social beliefs, culture, environment and the way things are perceived by the Westerners as compared to Nigerians could account for the different in results.

\section{Conclusion}

Based on the interpretation of findings of the data collected and analyzed, and discussion of results, it is concluded that teachers in the secondary schools in Anambra state perceived their school organizational culture to be good.

It has also been shown by the result of the study that the job performance of the teachers in secondary schools is good. This has been proven by majority of the teachers $89.3 \%$ scoring very high in their job performance. Deduced from one of the findings also is that teachers' attitudes to work in secondary schools is positive. This is evidenced by the high $84.0 \%$ attitude to work scores of the teachers.

The relationship existing between school organizational culture and teachers' job performance in secondary schools is not significant. Thus, there is no significant relationship between school organizational culture and teachers' job performance as perceived by teachers of different genders.

Finally, the relationship existing between school organizational culture and teachers' attitude to work is not significant. Thus, there is no significant relationship between school organizational culture and teachers' attitudes to work as perceived by teachers of different genders.

\section{Recommendations}

The following recommendations were made based on the findings of the study:

i. School management/principals and management of Anambra State post primary school service commission should ensure there is improvement in the secondary schools' culture in the state. Although, the school culture is perceived to be good by majority of the teachers, there is evidence that there is other aspects of their school cultures that are poor as identified by the very few 
Emengini, Omenyi \& Nwankwo: Organizational Culture as ...

teachers. Thus, the need for improvement in order to ensure that all the teachers perceive their school culture to be good.

ii. There is need for in-service training to be organized for all teachers in order to ensure that all the teachers in the secondary schools have good job performance without having few others that would rate their job performance poorly as found by the study. This could be through seminar, workshop, advance learning and the likes.

iii. There is also need for improvement in teachers' attitude to their work. This is because, even though majority of them have positive attitude to work there are others who have negative attitude to their work as identified by the few teachers.

\section{*Boniface Emengini, PhD}

Professor, Department of Educational Management and Policy, Faculty of Education, Nnamdi Azikiwe University, Awka bi.emengini@unizik.edu.ng

\section{*Ada Sam Omenyi, PhD}

Professor, Department of Educational Management and Policy, Faculty of Education, Nnamdi Azikiwe University, Awka as.omenyi@unizik.edu.ng

\section{*Christopher Amobi Nwankwo, PhD}

Professor, Department of Guidance and Counselling, Faculty of Education, Nnamdi Azikiwe University, Awka ca.nwankwo@unizik.edu.ng 


\section{References}

Adeyemi, T.O. (2008). Organizational climate and teachers' job performance in primary schools in Ondo state, Nigeria: An analytical survey. Asian Journal of Information Technology, 7(4), 138-145.

Aftab, H. \&Rana, T.\&Sawar A. (2012). An investigation of the relationship between organizational culture and the employees role based performance: evidence from the banking sector. International Journal of Business and Commerce, 2(4) 1-13.

Anambra State of Nigeria (2019).Post primary school service commission, Awka: state education zones staff analysis second term.

Aurah, C.\&Mcconel, T. (2014). Comparative study on pre-service science Teacher self-efficacy beliefs of teachers in Kenya and the United State of America U.S.A. American Journal of Educational Research 2 (4) 233-239.

Barros, S. \& Marcos, F.E. (2010). Physics how do they affect the reality of the classroom and models for change. http//www.physics.Ohio.State edu/Jossen/ICPE/0.2.html.

Bilali, O. (2013). Teaching efficacy to student teachers in the faculty of education, Elbasa, AlbamiaJournal of Education and Social Research, 3 (1) 179-185.

Chatman, J. Denison, D. Kuenzi, M. \& Schneider, B. (2012).Contrasting culture strength and climate.see http://www.denisonconsulting.com/.../contrasti, http://www.denisionconsulting.com/sitemap.

Cheng, Y.C (1993). A profiles of organizational culture and effective school. An International Journal of Research, Policy and Practices. 4(2) 1-9

Davoren, J, (2013). Organizational culture and employee performance/Chron.com http://www. Weakvsstrong/OrganizationalCulture \&Employee Performance.

Griffin, R.W. (2012). Relationship between organizational climate and performance of teachers in public and private colleges of punjab. Unpublished Doctoral Dissertation.University 
Emengini, Omenyi \& Nwankwo: Organizational Culture as ...

institute of education and research, pirmehr Ali Shah, Arid Agriculture University Rawalpindi and University Rawalpindi.

Hussain, S., Ali, R., Kha, M.S. Ramzan, M. \&Qadeer, M.Z. (2011).Attitudes of secondary school teachers towards teaching profession.International Journal of Academic Research, 3(1), 985-990.

Jex, S.M. \& Britt, T.W. (2008). Organizational psychology: A scientific practitioner approach. Hobo Ken, N.J: John-Wiley $\&$ Sons.

Joshua, A.A. \&Ifedayo, A.E.R. (2012).Teachers' instructional task performance and quality assurance of students' learning outcomes in Nigerian secondary schools.International Journal of Research Studies in Educational Technology, 1(1) 33-42.

Kamalu, N.S.M., Samsu, N.Z. \&Selamat, N. (2013).The impact of organizational climate on teachers' job performance.Educational Research Journal.2(1), 71-82

Karr, C. (2011). The attitude of teachers towards teaching reading in the content area in South Trinidad.MED Thesis, university of the West India.

Kashyap, V., Vohra, P., \&Kaur, T. (2012). Comparative analysis of organizational culture: The empirical study of IT organization in the region of Mohali (Punjab, India). International Journal of Management and Business Studies, 2(3) 60-64.

Kreitner, R. \&Kinicki, A. (2007).Organizational behaviour. Arizona: McGraw-hill Ryerson

Kumar, M.D., (2006). Strong and weak organizational culture implications retrieved 6/7/2014 from $<$ http://www.Indiviual Mba.com/faculty.../fc262.ht...

Luo, Z., Shi, K., Li, W. \&Miano, D. (2008). Construct of job performance. evidence from Chinese millitary solders. Asian Journal of Social Psychology, 11(2), 222-231.

Maliki, A.E. (2013). Attitude of teachers' in Yenagua local government area Bayelsa State-Nigeria, towards the 
Ogirisi: a new journal of African studies vol. 162020

teaching profession: Counseling implications. International Journal of Research in Social Sciences, 2(2), 33-38.

Nduanya, M. (2000).Discipline, profession ethics and the Nigerian teacher.In Nnana O.C. and Mkpa.M.A. (Eds.) Readings in discipline and motivation pp 46-57.Dwer: Barlos publishers Inc.

Ng'ang'a, M.J. \&Nyongesa, W; (2012).The impact of organizational culture on performance of educational institutions.International Journal of Business and Social Science, 8(3), 22-25.

Nworgu, B.G. (2015). Educational research basic: Issues and methodology. $\left(2^{\text {nd }} \mathrm{ed}\right)$ Enugu: Trust publishers.

Obineli, A.S (2013). Teachers' perception of the factors affecting job satisfaction in Ekwusigo L.G.A of Anambra state, Nigeria.AnInternational Multi Disciplinary Journal of Ethiopia. 7 (4) 225-237.

Ogunbowale, O. (2007). Organizational climate as a predictor of employee job satisfaction.African Journal of Education and Development at Studies 2 (3)4-9

Ololube, N.P. (2006). Teachers job satisfaction and motivation for school effectiveness: An assessment.

http://www.usca.edu/essays/.../ololube.pdf.

Onunkwo, G.I.N. (2002). Fundamentals of education measurement and evaluation. Owerri: Cape publishers Int.1 Ltd.

Owoyemi O.O. \&Ekwoaba, J.O. (2014). Organizational culture: A tool for management to control, motivate and enhance employee's performance. American Journal of Business and Management, 3(3).168-177.

Raza, S.A. \&Sha Arid, P.M.A. (2010).Impact of organizational climate of performance of college teachers in Punjab.Journal of College Teaching and Learning, 7(10), 47-52.

Riley, J. (2013). Organization culture: strong v. weak retrieved 6/7/2014from///E://weak vs strong/organization culture strong v. weak. html.

Robbins, S.P. (2005). Organizational behavior.Element edition Pearson prentice hall, Upper Saddle River, New Jersey. 
Emengini, Omenyi \& Nwankwo: Organizational Culture as ...

Sullivan, L. (2010). The influence of school culture, school goals, and teacher collaboration on the teachers' attitudes toward their professional development plans. Unpublished PhD dissertation, George Masson University.

Suwannoppharat, K. \&Kaewsa, A. (2015) Utilization of contenttheme- based instruction: An overhaul of english language learning for non-native English learners. International Journal of English Language Education. 1 (3) 115-126.

Wang, H.C., \& Hwang, F. (2007). Study on organizational culture, organizational commitment and attitude towards organizational reform-comprehensive high schools as example. Journal of Human Resource andAdult Learning,3 (2) $189-198$

Yasil, S. \& Kaya, A. (2012). The role of organizational culture on innovation capability: An empirical study. International Journal of Information, 6 (1) 11-25. 